\title{
Factors That Have Led to the Collapse of the Bretton Woods System
}

\author{
Yueru Jin ${ }^{*}$, Duanyi Liu' ${ }^{2}$, Yuhan $\mathrm{Li}^{3}$ \\ ${ }^{1}$ Dalian No. 24 High School, Dalian, China \\ ${ }^{2}$ Seoul Foreign School, Seoul, South Korea \\ ${ }^{3}$ NO. 1 Middle School Affiliated to Central China Normal University, Wuhan, China \\ Email: ^1224154544@qq.com
}

How to cite this paper: Jin, Y.R., Liu, D.Y. and Li, Y.H. (2018) Factors That Have Led to the Collapse of the Bretton Woods System. American Journal of Industrial and Business Management, 8, 2133-2142. https://doi.org/10.4236/ajibm.2018.810141

Received: September 11, 2018

Accepted: October 20, 2018

Published: October 23, 2018

Copyright (c) 2018 by authors and Scientific Research Publishing Inc. This work is licensed under the Creative Commons Attribution-NonCommercial International License (CC BY-NC 4.0). http://creativecommons.org/licenses/by-nc/4.0/

\begin{abstract}
The Bretton Woods system was abandoned by the U.S. government in 1971 . In order to learn to avoid the structural flaws that led to the collapse and ensure a more stable economic condition in the future, this article aims to research the cause of the collapse. It elaborates on the two main causes of the Bretton Woods system: structural ones, such as the incompatible role of the USD and the conflicting sovereign goals, and the operational ones, such as the reluctance of other countries to follow the exchange rate rules. It then displays viewpoints from these two causes, and analyses them, that is, strengthens or undermines them, with facts and reasoning. Finally, it reaches the conclusion that the Bretton Woods system broke down in 1971 due to structural factors instead of operational ones and gives some brief lessons from the failure.
\end{abstract}

\section{Keywords}

The Bretton Woods System, Structuralists' View, Operationalists' View,

Triffin's Dilemma, Pegging System, Game Theory, Fundamental

Disequilibrium

\section{Introduction}

\subsection{Background}

The international dominance of pound sterling was weakened during WWI, leading to the restoration of gold standard. After WWII, the government of US and Britain managed to rebuild a postwar international monetary system that both catered to their own national interest and stimulated the world economy. Thus, White Plan, from the interest of the US, and Keynes Plan, from the inter- 
est of Britain, were put forward. As the US became the leader of capitalist country due to its advantage gained from world economic crisis and WII, the status of the USD was stabilized because of its huge gold reserve resulted from trade surplus. Therefore, in July 1944, Bretton Woods, a system that closely reflected the goal of the US, was established. Capital liberalization, foreign exchange liberalization, and trade liberalization were the three pillars of the multilateral economic system.

\subsubsection{There Are Two Institutions in the Bretton Woods System}

1) IMF, short for International Monetary Fund, provides short-term financial loans for countries in serious economic crisis, in order to maintain balance of international payment and safeguard the stability of the international monetary system.

2) International Bank for Reconstruction and Development (IBRD), now known as World Bank, provides medium and long-term loans and technical assistance for member countries or private enterprises secured by governments, in order to promote economic recovery of member counties and the balanced growth of international trade and payments.

\subsubsection{There Are Six Main Features of the Bretton Woods System}

1) The Dollar is pegged to the gold. The official gold price that US government regulated is 35 dollars for one ounce of gold.

2) All other currencies are pegged to the dollar. Other governments set their exchange rates to dollars by the gold standard.

3) Adjustable fixed exchange rates. The exchange rate between other currencies and dollars can only fluctuate within $1 \%$ on the basic of legal exchange rate.

4) The principle for currency conversion and international payment and settlement. Member countries are not allowed to set restriction for international payment and settlement.

5) The USD as a reserve currency. The USD works as the international reserve currency to compensate for the short supply of gold.

6) The adjustment of international payment.

In this scenario (Figure 1), betraying each other becomes the best option of both prisoners. "Because betraying a partner offers a greater reward than cooperating with them, all purely rational self-interested prisoners will betray the other, meaning the only possible outcome for two purely rational prisoners is for them to betray each other (Nicholas, 2014) [1]."

This theory applies to devaluation in currency in the Bretton Woods system period as well (Figure 2).

Given the payoff matrix, the optimal option for the two countries is to devalue their currency when they are not sure what the counterparty will do. When one of them devalues its currency while its counterparty does nothing, the country that devalues its currency will gain a bargain.

Decolonization is a period of time after the WWII where overseas territories 
of big empires such as the Great Britain and France gained independence. Decolonization negatively affected Britain. Therefore, in order to reform its economy, bilateral trade with the United States was its best and most efficient choice, since the US was one of the strongest and most economically stable countries during the post war period (Figure 3 and Figure 4).

Figure 4 shows the change in exchange rate of Euro to USD (1 Euro to USD) from 1953 to 1971, which includes the latter period of the Bretton Woods system when problems began to appear and the three Dollar Crisis of the United States. As labeled in the graph, during the first dollar crisis in 1960, the exchange rate dropped rapidly from around 0.99 to around 0.95 . It continued to drop during the second dollar crisis in 1968 and the third one in 1971, which happened right before the collapse of the Bretton Woods system.

\subsection{Our Objectives and Methods}

Many previous work have been done to research the cause of the breakdown of the Bretton Woods system. This article synthesizes them and groups them into two categories which are mentioned in Han's (2013) work: structural factors and operational factors. Then, it weighs and analyses divergent viewpoints in depth within a historical context. The method is mainly to support and undermine different factors using other researches and data. At last, the article comes to the conclusion in support of structuralists' view.

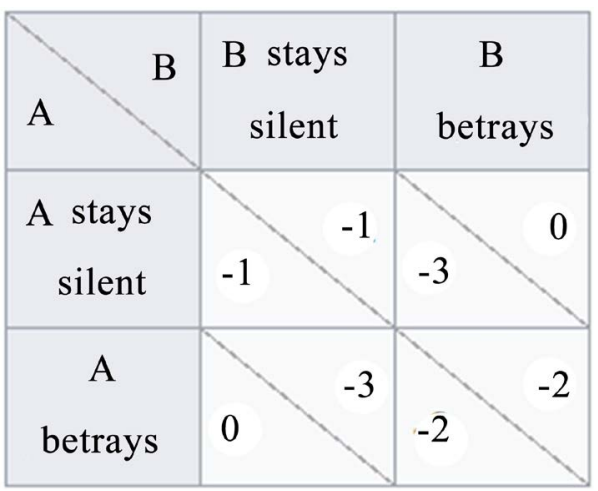

Figure 1. Prisoner's dilemma payoff matrix. (Elena Nisioti, May 12, 2018, In need of evolution: game theory and AI. Retrieved from https://medium.freecodecamp.org/game-theory-and-ai-where-it-all -started-and-where-it-should-all-stop.)

Foreign

Devalue

Home Not devalue

Devalue

\begin{tabular}{|l|l|}
\hline 0,0 & $-\mathrm{a}, \mathrm{a}-\mathrm{C}$ \\
\hline $\mathrm{a}-\mathrm{C},-\mathrm{a}$ & $-\mathrm{C},-\mathrm{C}$ \\
\hline
\end{tabular}

Figure 2. Payoff matrix of devaluation of currency during Bretton Woods period. ("a" stands for trade surplus, "C" stands for cost, assume that a > C, Dominguez 1992 (3).) 


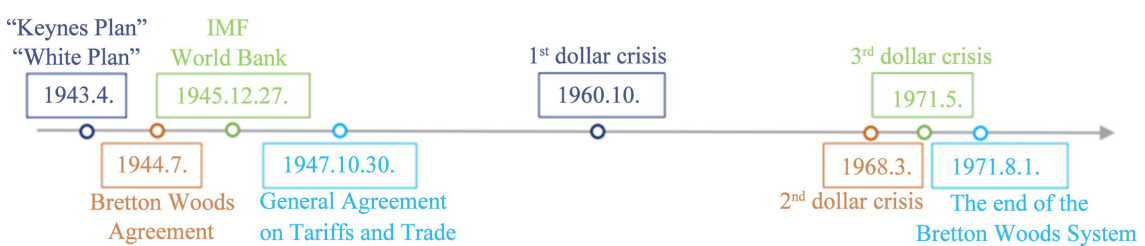

Figure 3. Timeline of the dollar crisis during the Bretton Woods system period.

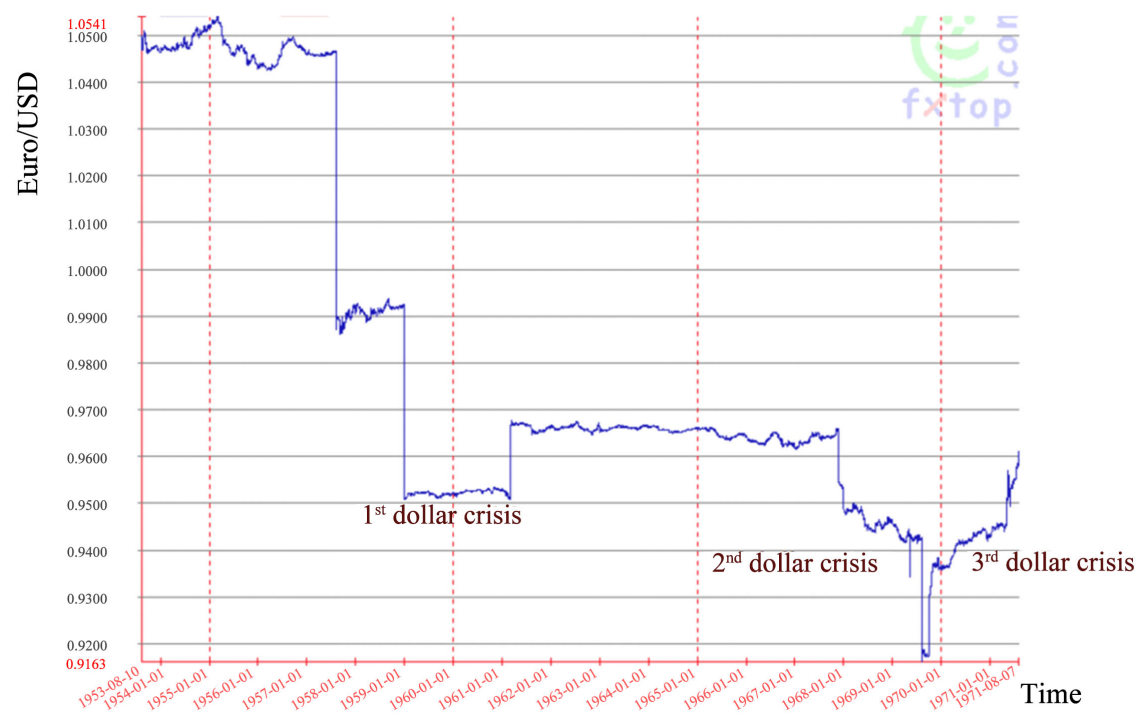

Figure 4. The exchange rate between USD and Euros during the Bretton Woods period. (Laurent PELE. "Historical Rates." Historical Exchange Rates from 1953 with Graph and Charts.)

\subsection{Overview of the Article}

First, structural factors play an essential role in the breakdown of the Bretton Woods system. Han (2013) [2] claims that the structuralists believe that it was the deficit in the Bretton Woods system itself that caused the breakdown. First, the incompatible role of USD set an unsteady foundation of the Bretton Woods system. Triffin (1960) [3] believes that one requirement of the role of USD would necessarily result in trade deficit of USD, that is, an outflow of dollars with an aim of increasing other country's foreign reserves. The other requirement, an inflow of dollars, would result in trade surplus, stabilizing the dollar as the central currency.

Wolff (2013) [4] provides details about another structural failure in his article to support the structuralists' point of view: the conflicting sovereign goals. Wolff argues that conflicting sovereign goals and self-interests of the big powers of the conference, Britain and the United States, have caused decolonization, which was one of the main dilemmas faced by the system during the 1960s.

Han (2013) also put forward some operational factors that led to the collapse of Bretton Woods system. He argues that the uncooperative gold accumulation behavior of other countries caused the depreciation of USD. However, this viewpoint has deficits and can be explained by other factors. US has accumulated 
huge war debt that would lead to inflation and depreciation of USD as a result of the US government kept printing money. Besides, the game theory (Dominguez, 1992) [5] can also account for the depreciation of USD.

In addition, from operationalists' points of view Han believes that the reluctance of member countries to alter exchange rate resulted in capital immobility, which foreshadowed the collapse of the Bretton Woods system. However, this argument can also be undermined by two structural defects. For one thing, an important term "fundamental disequilibrium" in the agreement was "not well defined" (Obstfeld, 1991) [6]. For another, the pegging system was flawed. Since other countries had to peg their currency to the USD, capital mobility was reduced.

\section{Structuralists' Views}

The Bretton Woods system may have failed structurally due to conflicting sovereign goals. In fact, Gardner (1985-86, p. 21) regards the post war settlement of Bretton Woods system as a "political miracle", since "the postwar period promised rising economic vulnerabilities for all nations" and "the two governments held markedly different views during the initial negotiations over postwar trade and monetary relations" (Bordo, 1993) [7]. However, this miraculous establishment finally ended owing to problems resulting from the divergent objectives of America and Britain. On the British side, as put forward by Wolff (2013) [4], "Britain recognized that the potential exploitation by the war's victors of the defeated Axis Powers [could] lead to another global disaster". Thus, it aimed to restore full employment by "[retaining] the imperial preferential system and bilateral trading" that was undermined in WWII. In other words, Britain favored bilateral trading with the US since it was an effective way of recovering its economy that has been damaged by joining the war. The US, on the other hand, intended to establish multilateral trade as a means of expanding its thriving economy and helping other European countries to reform their economies.

Apart from the explicit difference in trade forms, free trade as opposed to bilateral trade, Han (2013) explains yet another aspect of incompatibility of the two countries' goals; he argues that "the aim of full employment precluded deflationary remedies for external balance". To put it another way, full employment, the goal of Britain, can lead to inflation. However, since the US had trade surplus before the Bretton Woods system, it aimed to appreciate its dollars, thus resorting to means of deflation. These differences are problematic because it is difficult for US and Britain to cooperate and maintain the Bretton Woods system if the objective of one of them is realized at the expense of another. In effect, although "international trade grew rapidly and consistently during the 1950s and 1960s" as shown in "between 1948 and 1960, the total value of merchandise exports of non-communist countries rose from $\$ 53$ billion to $\$ 112.3$ billion", which satisfied the US, Britain's goal failed, since "Current account restrictions inhibited bilateral trade during early stages of [the Bretton Woods system]" 
(Terborgh, 2003) [8]. Furthermore, Britain faced serious trade deficit and was unable to recover its post war economy. This ultimately resulted in Britain depreciating its currency at the end of 1967, violating the rules set by the Bretton Woods system. To sum up, the Bretton Woods system did not satisfy the need for both countries and therefore created violation that precipitated the ultimate collapse.

Despite the success in achieving multilateral trade, problems arose in the US itself as well; the role of USD as reserve currency caused considerable turbulence in the financial system. This paradox is known as "Triffin Dilemma" (1960) [3], in which Triffin articulates two conflicting roles USD had to take. For one thing, the USD requires an outflow of currency to replenish the foreign reserves in the rest of the world. However, since that in turn leads to trade deficit, the USD is destabilized, which disrupts the stability of the global financial system. For another, an inflow of USD is also required so as to strengthen its role as the currency to which other countries pegged fixed exchange rates. The result, as Zhou (2009) [9] points out, becomes "[the monetary authorities] may either fail to adequately meet the demand of a growing global economy for liquidity as they try to ease inflation pressures at home, or create excess liquidity in the global markets by overly stimulating domestic demand." In other words, it is difficult for one currency to serve dual purposes.

Triffin's prediction was realized under the Bretton Woods system. As America continued to face trade deficit and US liabilities surged during the Bretton Woods period, the USD depreciated to the point that was incompatible to the value of gold. As a result, other countries converted their dollar reserves into gold one after another. The massive inflow of USD in exchange of gold not only dissatisfied one of the US's initial goals, which was for the USD to become the world's central currency, but also resulted in a depletion of gold reserves of the US, which undermined the stability of the USD. All these events culminated in Nixon's announcement that the USD was no longer pegged to the gold standard in 1971, which was the sign of the breakdown of the Bretton Woods system. Besides Triffin, other economists foresaw the defects in the Bretton Woods system as well. In 1941, Keynes proposed a more appropriate alternative to USD as global reserve currency called "bancor", because he claims that a new currency can prevent the breakdown of one currency's incompatible purposes. However, this proposal was rejected by the American government. Ultimately, the latent fatal weakness of USD as a dual-purpose currency exacerbated and led to the ultimate breakdown.

\section{Operationalists' Views and Why They Do Not Work}

The operationalists, in contrast, believe that the problem lies in the mismanagement of Bretton Woods system. Han (2013) [2] points out that the uncooperative behavior of the European countries deviated from the original design of the system. Since US controlled most of the gold at the beginning of the Bretton 
Woods system, it was able to appoint USD as the reserve currency and let it replace gold as the central currency. However, European countries still relied on gold; "[they] accumulated gold despite the attempt by the US to dissuade massive gold conversions." This result not only did not satisfy the ultimate goal of the US, but also led to large depletion of gold in US reserves, leading to inflation and the depreciation of the USD. Acknowledging the undesirable outcome, the US decided to no longer make available for country to exchange USD for gold, announcing the end of the Bretton Wood system.

However, the uncooperative behavior of European countries may not be wholly held responsible for the depreciation of USD, which ultimately resulted in the failure of the Bretton Woods system. The US had also entered several wars during the Bretton Woods period, which means that the depreciation of dollar may have also been caused by its huge debt accumulated through war expense. Besides, according to the experiment of game theory (Dominguez, 1992) [5], any country that does not fix the exchange rate as indicated in the Bretton Woods system and depreciate its currency can have an advantage over other countries. Dominguez argues that exports were facilitated through that currency depreciation, and exports were necessary during the post war period when countries were finding ways to get out of economic recession. Therefore, some countries saw this benefit and deviated from the original rule of Bretton Woods system; "Canada, France, Germany, the Netherlands, and Mexico suspended fixed currency valuations without consultations with the IMF, which violated article 4 of the Agreement" [3]. Both of the explanations are alternatives to the operationalists' view that management flaws are the main cause of the breakdown of the Bretton Woods system.

Operationalists put forward another management flaw by arguing that other countries failed to comply with the adjustment of exchange rate assigned in the Article of Agreement. In the agreement, there was a term called "fundamental disequilibrium", which means that countries had rights to adjust their exchange rate at the range of $1 \%$ when outward and inward payments did not balance. However, other countries did not follow the agreement. "Although exchange rates can be altered in case of "fundamental disequilibrium", countries were reluctant to alter their currency values, since "[they fear] that would indicate the weakness of the currency" (Han, 2013) [2]. Obstfeld has shown in his paper (1991) [6] that this reluctance had the setback of "[countries] were [being] constrained to lower levels of investment and higher levels of saving than probably would have prevailed with full capital mobility". Capital immobility, in turn, hindered trade among countries. Since encouraging free trade was one of the initial goals of the Bretton Woods system, it was undermined by capital immobility, leading to the collapse of the Bretton Woods system.

Nevertheless, Obstfeld (1991) [6] proposed another possible reason for this capital immobility, that is, the structural limitation of the policy, because the term "fundamental disequilibrium", the situation under which countries can change their exchange rates, "was not well defined". More explicitly, the condi- 
tions under which countries were able to exercise the policy were not specified. As a result, countries were careful about altering their exchange rates. In addition, another structural flaw may have predetermined the failure of the Bretton Woods system. Since "In the Bretton Woods regime currencies were pegged to the dollar, which in turn was tied to gold", "capital mobility was limited" (The Economist Nov $\left.4^{\text {th }}, 2010\right)$. This implies that it is not the management of exchange rate system but structural flaws that led to the failure of Bretton Woods system. It follows that some countries' violations may be preceded by the structural flaws instead of operational ones.

\section{Lessons Learned from the Collapse of the Bretton Woods System}

Considering the structural flaws of the Bretton Woods system discussed above, fixed exchange rate should be changed into floating exchange rate. Eichengreen (2004) [10] argues that "The further decline in the dollar will be a good thing for the adjustment of global payments imbalances." In other words, it is better to adopt a floating exchange rate that reflects the global economy. In recent years, Asian markets have been thriving and created a rising demand that led to appreciation of their currency. However, the currency in Asia would fail to experience appreciation if the currency in Asia were pegged a fixed exchange rate to the dollars and other currency. Conversely, a floating exchange rate would create a better international balance. However, some regulations of the exchange rate system is still needed. The Jamaica Monetary system, which was created after the breakdown of the Bretton Woods system and centered on floating exchange rate, has experienced strong turbulence owing to the rapid change of exchange rate.

Second, a successfully designed agreement is also needed to sustain a system. In the case of Bretton Woods as discussed above, the flawed design of Bretton Woods agreement precipitated the uncooperative behavior of its member countries. Therefore, to prevent these detrimental defaults, a restraint mechanism should necessarily be set. First of all, countries should be given the incentive to cooperative even not under optimal conditions. In other words, although countries during the Bretton Woods system would be better off break the agreement and devalue their currency, they would still choose to cooperate because they would be promised to be compensating for their loss. O’Brien and Gowan (2012) [11] proposes that there should be "agreements build in mechanisms to facilitate compliance in [countries]". They then give an example- "Montreal established a Multilateral Fund to subsidize developing countries' compliance expenses, with success". In this way, countries are secured against potential loss of compliance, and may cooperate more effectively. In addition, countries should be mandated to "pay" for their uncooperative behavior, or even receive a sanction. O'Brien and Gowan (2012) [11] also points out that making a public announcement of default countries and imposing trade restrictions are two effective measures of discouraging the noncompliance behavior. Under this circumstance, every 
country would weigh the cost and benefits more cautiously before making decisions to default in the agreement.

\section{Conclusions}

This article researches the causes of the collapse of the Bretton Woods system. It comes to the conclusion that structural flaws are the main causes of the breakdown, and puts forward some brief lessons that are useful to ensure a more stable international monetary system. Specifically, it supports two important structuralists' views: the incompatible role of the USD and the conflicting goals of the then world's two superpowers. To emphasize the importance of the structuralists' view, this article also undermines two alternative operationalists' views, stressing that it was basically the underlying structural flaws that have led to the mismanagement of the Bretton Woods system. Therefore, a lesson naturally comes up: a well-designed structure of the system is needed in order to successfully implement it.

This article analyses a number of viewpoints of the cause of the breakdown of the Bretton Woods system from various papers and presents a conclusion based on the evaluation of the validity of these views according to the historical context. This article focuses mainly on qualitative measures and may not include adequate models or graphs. It only explains and evaluates different factors that have led to the breakdown of the Bretton Woods system without plotting them in different graphs to verify the effect. Therefore, further quantitative researches could be done. Further research could focus on mathematical simulations of the effect of different factors on the exchange rates, which clearly shows the significance of each factor.

\section{Acknowledgements}

We would like to express our sincere appreciation to Dr. David C. Shimko of NYU for his valuable suggestions and guidelines for this research program.

We would also like to thank CIS for offering us an opportunity to engage in scientific research training.

\section{Conflicts of Interest}

The authors declare no conflicts of interest regarding the publication of this paper.

\section{References}

[1] Milovsky, N. (2014) The Basics of Game Theory and Associated Games.

[2] Han, C.B. (2013) Bretton Woods: Doomed Failure from the Beginning? The Interplay of Structural and Operational Factors in the Gold Pool. The Undergraduates Award Library.

[3] Triffin, R. (1960) Gold and the Dollar Cris: The Future of Convertibility. Yale University Press, New Haven, Connecticut.

[4] Wolff, M.J. (2013) Failure of the International Monetary Fund \& World Bank to 
Achieve Integral Development: A Critical Historical Assessment of Bretton Woods Institutions Policies, Structures \& Governance. Syracuse Journal of International Law \& Commerce, 41, 71 .

[5] Dominguez, K.M. (1993) The Role of International Organizations in the Bretton Woods System. In: A Retrospective on the Bretton Woods System: Lessons for International Monetary Reform, University of Chicago Press, Chicago, 357-404.

[6] Obstfeld, M. (1993) The Adjustment Mechanism. In: A Retrospective on the Bretton Woods System: Lessons for International Monetary Reform, University of Chicago Press, Chicago, 201-268.

[7] Bordo, M. (1993) The Gold Standard, Bretton Woods and Other Monetary Regimes: An Historical Appraisal. National Bureau of Economic Research, No. w4310.

[8] Terborgh, A.G. (2003) The Post-War Rise of World Trade: Does the Bretton Woods System Deserve Credit?

[9] Zhou, X.C. (2009) Reform the International Monetary System.

[10] Eichengreen, B. (2004) The Dollar and the New Bretton Woods System. Thornton Lecture, Cass Business School, London.

[11] O’Brien, E. (2012) What Makes International Agreements Work: Defining Factors for Success. Center on International Cooperation. 